\title{
Matrix support in mental health in primary care: the vision of supporters and nurses
}

\author{
Apoio matricial em saúde mental na atenção básica: \\ a visão de apoiadores e enfermeiros \\ Apoyo matricial en salud mental en la atención primaria: \\ la visión de profesionales de apoyo y enfermeros
}

\author{
Gustavo Costa de Oliveira ${ }^{a}$ (iD) \\ Jacó Fernando Schneider ${ }^{b}$ \\ Leandro Barbosa de Pinho ${ }^{b}$ \\ Marcio Wagner Camatta ${ }^{b}$ \\ Cíntia Nasib \\ Andréa Noeremberg Guimarães ${ }^{c}$ \\ Maria Eduarda de Lima Torres ${ }^{b}$
}

How to cite this article: Oliveira GC, Schneider JF, Pinho LB, Camatta MW, Nasi C, Guimarães AN, Torres MEL. Matrix support in mental health in primary care: the vision of supporters and nurses. Rev Gaúcha Enferm. 2020;41(esp):e20190081. doi: https://doi.org/10.1590/19831447.2020.20190081 a Universidade Federal do Rio Grande do Sul (UFRGS), Programa de Pós-Graduação em Enfermagem. Porto Alegre, Rio Grande do Sul, Brasil.

- Universidade Federal do Rio Grande do Sul (UFRGS), Escola de Enfermagem, Departamento de Assistência e Orientação Profissional. Porto Alegre, Rio Grande do Sul, Brasil.

Universidade do Estado de Santa Catarina (UDESC) Departamento de Enfermagem CEO. Chapecó, Santa Catarina, Brasil.

\section{ABSTRACT}

Objective: To understand the view of supporters and nurses on matrix support mental health actions in Primary Health Care.

Method: A qualitative and phenomenological study, with Alfred Schutz's framework of phenomenological sociology. The study was conducted with five supporters and 22 nurses from Basic Health Care Units in the city of Porto Alegre. The participants'intentions and expectations, captured through a phenomenological interview, made up the corpus of analysis.

Results: The supporters have the intention, given the actions of the matrix support, to improve mental health care for the user. On the other hand, the nurses expect support to the health units, which reveals nonconformities in the mental health practices instituted in the basic network. Final considerations: Knowing the motivations of supporters and nurses can be a powerful strategy for consolidating public policies with a view to the psychosocial way in the territory.

Keywords: Nursing. Psychiatric nursing. Mental health. Primary health care. Mental health assistance. Philosophy.

\section{RESUMO}

Objetivo: Compreender a visão de apoiadores e enfermeiros sobre as ações do apoio matricial em saúde mental na Atenção Básica à Saúde. Método: Estudo qualitativo, fenomenológico, com o referencial da sociologia fenomenológica de Alfred Schutz. Participaram do estudo cinco apoiadores matriciais e 22 enfermeiros de Unidades de Saúde da Atenção Básica do município de Porto Alegre. As intenções e expectativas dos participantes, captadas por meio de entrevista fenomenológica, compuseram o corpus de análise.

Resultados: Os apoiadores têm a intenção, diante das ações do apoio matricial, de melhorar o cuidado em saúde mental ao usuário. Por outro lado, os enfermeiros esperam suporte do apoio às unidades de saúde, o que revela desconformidades nas práticas em saúde mental instituídas na rede básica.

Considerações finais: Conhecer e compreender as motivações de apoiadores e enfermeiros pode ser uma potente estratégia para a consolidação de políticas públicas com vistas ao modo psicossocial no território.

Palavras-chave: Enfermagem. Enfermagem psiquiátrica. Saúde mental. Atenção primária à saúde. Assistência à saúde mental. Filosofia.

\section{RESUMEN}

Objetivo: Comprender la visión de los profesionales de apoyo y de los enfermeros sobre las acciones del apoyo matricial en salud mental en la Atención Primaria de la Salud

Método: Estudio cual itativo y fenomenológico, conel referencial desociología fenomenológica de Alfred Schutz. Participaron cinco profesionales de apoyo matricial y 22 enfermeros de Unidades de Atención Primaria de la Salud de la ciudad de Porto Alegre. Las intenciones y expectativas de los participantes, registradas por medio de entrevistas fenomenológicas, compusieron el corpus del análisis.

Resultados: Los profesionales de apoyo tienen la intención, ante las acciones de apoyo, de mejorar el cuidado en salud mental al usuario. Por otro lado, los enfermeros esperan apoyo a las unidades de salud, lo que revela inconformidades en las prácticas de salud mental instituidas en la comunidad.

Consideraciones finales: Conocer y comprender las motivaciones de los profesionales de apoyo y de los enfermeros puede ser una poderosa estrategia para consolidar políticas públicas con vistas al modo de acción psicosocial en el territorio.

Palabras clave: Enfermería. Enfermería psiquiátrica. Salud mental. Atención primaria de salud. Atención a la salud mental. Filosofía. 


\section{口 INTRODUCTION}

In the field of health and nursing, the care apparatus in force in the numerous scenarios of health care conceives new theoretical paths, as well as indicates new practical possibilities. To this end, field research has contributed to the tensioning of actions carried out in health services, in which the outcome evaluation needs to incorporate clinical, singular and social variables, a complex and comprehensive task in which the technical and relational skills of those involved produce a new synthesis, better suited to the reality of the territory ${ }^{(1)}$.

Over two hundred years, there have been numerous efforts to sharpen and adjust points related to mental health therapy. The struggle for overcoming the asylum apparatus, triggered by the Psychiatric Reform, implies the transformation of assistance to people in psychological distress ${ }^{(2)}$ for the services of the Psychosocial Care Network (Rede de Atenção Psicossocial, RAPS).

Given the demands and needs of mental health found in the territory, the Matrix Support in Primary Health Care was instituted as a strategy that seeks to increase the resolution of actions, proposing a reformulation in the mode of organization of the services and of the horizontal relations between the generalist and specialized network ${ }^{(3)}$. However, care practice points to the integration of mental health care networks within the community scope as an important difficulty ${ }^{(4)}$, in which health professionals, including matrix supporters and nurses, act disparate and distant, which weakens matrix consolidation.

This study is justified by the importance of understanding the view of matrix supporters and nurses on Matrix Support actions, giving visibility, respectively, to their intentions and expectations. Its relevance is based on the generation of subsidies to enhance the multi-professional, interactive and participatory work, strengthening the production of care in the territory as an instrument for life defense.

Such being the case, the question that guided this study was outlined as follows: How do supporters and nurses understand Matrix Support mental health actions in primary care, given Alfred Schutz's phenomenological sociology? Thus, the objective of the research is to understand the view of supporters and nurses on Matrix Support actions in mental health in primary care, given Alfred Schutz's phenomenological sociology.

\section{METHOD}

This is a qualitative research from the doctoral thesis referred to as "Matrix Support actions in mental health in primary care: supporters' intentions and nurses' expectations", of a phenomenological nature and with Alfred Schutz's framework of phenomenological sociology. The intentions and expectations explored in this study concern what Matrix supporters and nurses expect in relation to the Matrix Support in Primary Care, their interests, that is, according to Schutz's framework, the reasons for their actions. The reasons for are the ultimate reasons why the action was taken, which are forward-looking ${ }^{(5)}$.

Participants consisted of five matrix supporters and 22 nurses from the primary health care network. Inclusion criteria were as it follows ahead: being part of the functional staff of the city hall; being a matrix supporter or a nurse in some district region of Porto Alegre; not being on vacation and/or leave during the data collect period; and actuating in the service for six months or more.

Information was collected by means of phenomenological interviews in July and August 2017, at convenient times and locations for the study participants. The statements were recorded and transcribed in full, ensuring data veracity. All of the research's participants signed the Free and Informed Consent Form (FICF).

The following questions were used when conducting the interviews: For the Matrix Support components: "What mental health actions have you been doing together with Primary Care?" and "What do you mean by these actions?"; for the nurses: and "What do you expect from Matrix support mental health actions together with Primary Care?". For the participants' privacy, the statements were referenced by the letter " $\mathrm{A}$ " for matrix supporter (Apoiador) and " $\mathrm{E}$ " for nurse (Enfermeiro), followed by the interview number.

The analysis of the information took place given Alfred Schutz's framework of phenomenological sociology. To unveil the essence of the phenomenon, the following steps were followed ${ }^{(6)}$ : Attentive reading of the speeches in order to capture the experienced situation and the reasons for of the subjects; identification of concrete categories that house the acts of the subjects; rereading of the speeches in order to select and group excerpts that contained similar significant aspects of the subjects' actions. Finally, based on the typical characteristics of the speeches, the meaning of the actions of the subjects was established, seeking to describe the typical action of matrix supporters and nurses.

From the convergences of the units of meaning that emerged from the speeches, the results related to the experiences of matrix supporters and nurses were organized in two concrete categories: "The supporter intends to enhance mental health care to the user" and "the nurse expects support from the health unit teams". At the end of the analysis process, the devolution of the results was 
scheduled with the field of study, in order to contribute to mental health care in the community.

The ethical aspects on research with human beings, recommended by the National Health Council, were met according to Resolutions 466/2012 and 510/2016. The research project was submitted to Plataforma Brasil and was approved by the Research Ethics Committees of the Federal University of Rio Grande do Sul and the Municipal Health Secretariat of Porto Alegre under CAAE No. 63099916.2.0000.5347 and Opinion No. 2,014,999.

\section{RESULTS AND DISCUSSION}

From the analysis of the reports given Alfred Schutz's framework of phenomenological sociology, the following two concrete categories were submitted as the view of matrix supporters and nurses regarding their motivations: The supporter intends to enhance mental health care to the user and the nurse expects support from the health unit teams.

\section{The supporter intends to enhance mental health care to the user}

In the facet of the phenomenon regarding the view of the matrix supporters, the trend of these supporters towards enhancing mental health care to the user in the community context was evident. To this end, these professionals had as their foundation immediate interests such as autonomy and user monitoring, permeated by the face-to-face relationship.

In the Schutzian conceptual outline, the face-to-face situation allows for the apprehension of the other, which favors a close relationship among people, experienced given the conformation of a relationship of us. In this relationship, there is pure awareness on the presence of the other person, that is, the apprehension of the other comes from lived experiences, where consciousness flows together over a period of time, with multifaceted mirroring of each other ${ }^{(5)}$.

Mental health care to the user was configured as the knowledge of interpretative schemes for this user through interaction with their peers, since the supporters somehow were related to the user, being focused and related to them. Caring requires the definition of an interpersonal relationship where the people involved are aware of and mutually oriented in space and time ${ }^{(7)}$.

In the social world, the person is within the reach of my direct experience, as they share a spatial and temporal point with me. In considering the individuals who are within reach of the mundane experience of each other, a relationship of us was constituted, which was configured as the directly lived social relationship ${ }^{(6)}$. Given this, it was found that the understanding of the world in an intersubjective logic occurred through social interaction among people.

It is imperative, in this sense, to understand that the empowerment of mental health care to the user presupposed the establishment of a face-to-face relationship among supporters and users, as well as among supporters and health professionals from the health facilities, with intersubjectivity apprehended in the shared world. The intersubjective relationship with a view to the autonomy of the being, as an element of work in the territory, was also an immediate interest at the moment when the supporters reported, as an intention, that this autonomy assumed conditions of self-care and user responsibility during the therapy:

For them to perceive that they are able to get to do their treatment. [...] A matter of autonomy in the sense of responsibility. (A4)

[...] it is not for you to take all the responsibility. They have a co-responsibility. Then, you take the person's name, do all that co-responsibility thing. (A1)

Although these matrix supporters informed on the need to encourage accountability and autonomy of users, it appeared that these elements were also focused on the work of the Matrix Support and health unit staff, in a care compacting movement, where all the social actors were involved. The face-to-face social relationship is a direct relationship and establishes a typical relational community, where the subjects share experiences, make plans and act in the world, engaging in the same social situation in time and space(8).

Therefore, it is necessary to consider the elements being peculiar to the social interaction in the Matrix Support mental health actions, meeting Schutzian thought to unveil the studied phenomenon. In the midst of everyday life, such social interaction was mentioned by the matrix supporters, who in the context of the work related to the health professionals in meetings, as well as to the users throughout the health therapy:

We have a contact, monthly meetings with CAPS II, where we discuss cases. There are cases that are not resolved there. (A1)

For people to understand that they also have an accountability in that, and this autonomy comes [...] to assist in this care. (A4) 
Do the follow-up with this person, because it's not just a drug thing. (A2)

Following the guidelines, the Matrix Support proposes to institute the logic of co-management for interprofessional relations and to strengthen the territory teams in a co-responsible movement in mental health care, impacting the teams' work and the user's prognosis ${ }^{(9)}$. In this sense, mental health care requires user accountability to cope with psychological distress, thus encompassing to their daily life a care raised in the basic health network.

This made it possible to confront the lack of responsibility and the monopoly of care, which leads to the traditional model that only matrix teams have health responsibilities in face of the community's mental health demands ${ }^{(2)}$. In the health sphere, the pursuit of strengthening social relations may reflect on the understanding of contexts and experiences, as well as on the emergence of intentions to enhance and enhance Matrix Support actions in mental health.

Finally, this may provide opportunities for matrix supporters to expand the exchange of knowledge and experiences with professionals and users of Health Units, in which social action is planned, implemented and rethought in a world shared by all. In the following statements, it was evident that the supporters also have the immediate interest of monitoring the user's mental health:

I take care of that individual, they will have a first contact. The first appointment will be longer. (A4)

To be directing that family to take some actions at home, which are very common things. (A3)

Given the reports, it was found that monitoring the user with a view to the power of care also requires the appreciation of the first contact with this individual, as well as the inclusion of the family in mental health actions. With these movements, it became possible to perform health in the peculiarities of each person, since the implementation of contextual and social interventions was proposed, in which attention to individuality was given in the collective sphere of society, starting at the family core.

Therefore, it is necessary to structure care interactively without renouncing the professional knowledge, but valuing the existential and historical experience of the user and family ${ }^{(10)}$. However, users and their families end up suffering from the sensitive condition of the health network which, sometimes, does not provide moments of dialog among the social actors, which could contribute to the effectiveness of collaborative care between Primary Care and Mental Health ${ }^{(11)}$.
Because users experience the territory, strategies such as home care, homecoming, bonding and co-responsibility can contribute to the continuity of mental health care, enhancing self-care. When considering the health-disease process as a complex one, social and subjective factors were recognized, which demand from matrix supporters, as well as from other health professionals, practices that go beyond the technical domain, requiring something different from the protocol, based on the facets of the social actors involved in the care and the treatment alternatives:

To strengthen the issue of longitudinal care that that individual is part of that territory, of that team. [...] That they may perceive themselves in the matter of self-care; the importance of health. (A4)

[...] to find other treatment alternatives... They stay there for the rest of their lives, and they won't get better. [...] Health is not just disease, just medicine, it is about other things: leisure, social, work. (A2)

In communicating their immediate interests, matrix supporters showed longitudinal care and focus on the individual's contextual situation as important elements in user follow-up. With regard to the face-to-face relation, the supporter looked at the user and realized that the user was oriented towards them, that the user was looking for the subjective meaning of the words, of the actions and of what was going through the supporter's mind and that might be of interest to them.

In the Schutzian conception, the being will take into account the fact that the other is oriented towards him, and this will influence both his intentions towards the other and the way he acts towards that other ${ }^{(5)}$. This exchange of glances, this multifaceted mirroring of each other is one of the most particular features of this relationship of us, illustrated in the social relationship among supporters and users in the primary health care network.

Looking at this facet of the phenomenon under the foundation of the scientific literature and given Schutz's work, it was possible to understand the interests of matrix supporters regarding the empowerment of user care, since social interactions between supporters and users permeated the dynamic of the therapeutic process in mental health, based on the singularity, collectivity and social. Thus, the face-to-face Matrix Support interventions with the users were relevant, as they facilitated the mental health performance of the territorial teams and, at the same time, enhanced the care provided to the user in this scenario, in view of the autonomy and health monitoring in the territory. 


\section{The nurse expects support from the health unit teams}

On the other facet of the phenomenon regarding nurses, it is noteworthy that their expectations were not limited to the scope of care available in health units, whose guideline is based on meeting the recurrent mental health demands in the community. In the nurses' reports, there was a description of their experiences with regard to the desire of support to the Health Units' teams, bringing this expectation out of two immediate interests: trainings of the teams and participation of the Matrix Support in the care of the Unit.

The support to the teams of the Health Units was configured as a recognition of the biography of the professionals of the Units. The sedimentation of the whole lived by the subject, until a given occasion of their living, was characterized as their biographical situation, and becomes a parameter for their motivations and actions in the world of life ${ }^{(12)}$

In the interviews, it was noted that the nurses' expectation for support to the teams of Health Units reflected, at the same time, their interest in training these health teams. Such expectation was related to the biographical situation of the health professionals in the Units, among which were the nurses, and was characterized, at first, by their need to obtain theoretical-practical knowledge in the field of mental health to improve their performance in Primary Care:

[...] to do a training or something like that, because there is no use in listening and not knowing what to do with it. (E1) [...] lack of training. [...] I think it could be more worked on, go after the knowledge. (E3)

Well qualified, also to differentiate what would be a pathology. (E12)

I think team guidance, how to welcome this next user. (E14)

In the reports, an apprehension was noticed of the nurse who will welcome the user in psychological distress, stressed out in the need for training for reception and evaluation in mental health. In addition, there was lack of training aimed at the subjective aspects of care, such as crisis management, social interaction and therapeutic resources, which undermines the construction of an integrated action matrix/referral team in the territory ${ }^{(13)}$.

However, training is not a guarantee for the consolidation of psychosocial care in the community. In the midst of the work process, training is important in providing professionals with spaces to exchange doings, which can contribute to improvements in their daily activities. In scenarios where there is a shortage of training, it is relevant to assess the relevance of offering them, seeking to understand the ambience and contextual difficulties exposed by the professionals, reiterated in the following statements:

[...] This training could also have been, a greater reception to the demand of the professional in the basic unit. (E4)

[...] to understand the human being. [...] If only to perceive this. This is lacking within our capabilities of the health professionals. (E6)

[...] it would be needed in our group [...] to have guidelines, [...] : what topics we should discuss, what to offer them. (E8)

By visualizing these statements, the nurses considered the teaching-learning process as important for their performance within the Primary Care scenario, as they highlighted needs in relation to nursing care for users in psychological distress. There is also the importance given to the educational process to the team, in which permanent education enhances the knowledge, doings and practice of Primary Care professionals ${ }^{(14)}$.

Within this context of support to the teams of the Health Units, there was a gap between supporters and referral team, as the reports revealed a gap between performance and expectations in the different ways of caring for the user in the community. The low frequency of educational practices ends up hindering the exchange of knowledge necessary to diversify the practice in health services, overcoming unpreparedness and transforming care.

Because it is a pedagogical proposal, Matrix Support has the potential to develop permanent health education in the community; however, the interaction among professionals from different areas still presented itself as the main challenge, which hinders the expansion of care and the production of mental health in the basic network. The shared construction of mental health care goes beyond the scope of specialism and advances to the territories where people live, as the relationship between professionals is an essential component for promoting therapeutic interventions in social contexts ${ }^{(14)}$.

Each additional experience of the being in relation to the other broadens their knowledge on it. Together with the stock of knowledge, social actors define plans and actions according to certain biographical situations ${ }^{(7)}$. Within this intentionality, the nurses also expected the participation of Matrix Support in the care of the Unit, which marked the recognition of the biographical situation of the professional to the institution of health actions in this scenario: 
I think I need more partnership, to do and participate all together. [...] If there had been a reference to be able to exchange an idea. (E2)

I always expect support. I hope to be more supported. (E3)

[...] that is to support, to be there, either through another contact. Give a phone call, send email, come in a group. (E8)

In these statements, it was observed that nurses expected to share experiences about situations related to the demands on mental health imposed on health units, in order to establish a relationship with the matrix supporters in the daily work. Experiences were exposed about the absence of these supporters in the care of the units, resulting in feelings of helplessness. The nurses stated that these issues justify the opportunity to have support from the matrix team.

Matrix Support success in mental health at addressing issues within the community definitely depends on working together. However, it is not plausible to elect the responsible people for the obstacles to the operationalization of the support, and it is necessary to recognize the complexity surrounding its consolidation, in order to address the difficulties aimed at optimizing psychosocial care for users of the basic network ${ }^{(15)}$.

It is also necessary to consider other aspects that make up the obstacles that hinder the practices of Matrix Support, among which the high demand for assistance in Primary Care, the insufficient health network in the territory and, especially, the difficulty of social actors to share the health actions ${ }^{(9)}$ stand out. From this, the relevance of the exchange of knowledge among social actors, sharing responsibilities and jointly managing the community's mental health issues, was highlighted. In the anxieties reported by the nurses, it was noticed that the proximity among these actors was clearly of paramount importance for the accuracy of actions in mental health therapy:

I hope you will help me to come up with ideas, solutions, a better history, so that I can also make care plans so that I can continue to support the unit. (E16)

That may be more present, be wrapped around the teams. (E17)

[...] I think it would be very good to get [...] the participation for knowledge of all cases. (E13)

In developing Matrix Support, the sharing of responsibilities took place only through social relations among all workers. In this logic, valuing and investing in the relationship between individuals became elementary for establishing a work effectively shared and open to the health network ${ }^{(16)}$. At the same time, it is necessary to recognize that the daily life characterized by shared work is still a challenge for the Primary Care sphere, since the inconsistency of supporters in the care spaces, as well as the fragility in the construction of therapeutic groups, evident in the following speeches of nurses, are part of an arduous path with constant challenges:

[...] if you came to the unit, if you had a group in the unit, someone in the unit who did the group once a week, [...] it would be a hell of a support. (E1)

Greater participation, proposals, reorganization of networks, flows, formulation of therapeutic groups. (E11)

More actions and activities in the unit, for example, mental health groups. (E14)

Group activities, coexistence, where they can express themselves and talk. (E20)

It was clear from these statements that there was a need for effective therapeutic groups in the midst of mental health actions in the Units, which brought to light the recognition of the biographical situation of the workers, in order to plan, act and live, aggregating all the experiences lived by these individuals. In the context of health actions, mental illness is not an individual process, but a family and collective process. Likewise, the treatment requires teams to actively listen in these group spaces in order to contribute to the therapy focused on the user's situation ${ }^{(17)}$.

In the operationalization of the work, the understanding of the nurses' posture change to perform matrix support in Primary Care revealed the need to expand the therapeutic offerings of teams with psychosocial tools ${ }^{(18)}$, where reports of having been jointly supported affirmed the need to build more effective and productive therapeutic flows and projects. In this context, the matrix supporter articulates institutional goals with the knowledge and interests of workers and users, with a view to promoting spaces for communication and assistance for producing knowledge $\mathrm{e}^{(19)}$.

It is worth mentioning the importance of the supporters and nurses' view on the actions of Matrix Support in mental health in Primary Care, as it translated, given the Schutzian framework, the human social action in this scenario, taking into account the reflective process on social relations, basis for producing mental health to people.

\section{—FINAL CONSIDERATIONS}

From this study, it is clear that the Matrix Support mental health actions in the territory are intertwined with the motivations of matrix supporters and nurses, since the intentions and expectations permeate health care to the 
people and their families. By directing the Schutzian look to these professionals, it is possible to apprehend their experiences in the social world, which may lead to discussions and reviews of practices for the consolidation of matrix-based strategies in the basic health network.

Understanding the view of supporters and nurses on the Matrix Support actions in Primary Care allowed identifying meanings of mental health therapy in the territory, which need to be part of care planning, in order to qualify the care process. These meanings unveil needs that should compose the actions already carried out in the territory, highlighting the importance of autonomy, user monitoring, training and the mutual participation of supporters and nurses in the community.

In the clinical practice, such aspects should be concretized in existing actions, with a view to encompassing elements that raise the edification and renewal of mental health care in Primary Care, seeking protagonism in the Matrix Support. Thus, there is a mental health care intercessor to strengthen public policies aimed at the psychosocial mode, open to dialog, defender of human rights and citizenship, consistent with the need to effect the socio-family (re)insertion of the person in psychic suffering.

Finally, it is necessary to point out that a generalization of these results is not indicated, as the present study focused on a reality in which there was a limitation on the number of participants, as well as the use of a single scenario. Even so, the Matrix Support in Primary Care is considered as a relevant and fruitful theme for new research in the field of nursing and mental health, in order to highlight that there is a need to problematize the views of professionals, users and family to the extent sharing the social world becomes a challenge for all social actors, where the experience can be translated in producing health, citizenship and life.

\section{REFERENCES}

1. Amaral CEM, Torrenté MON, Torrenté M, Moreira CP. Matrix support in Mental Health in primary care: the effects on the understanding and case management of community health workers. Interface (Botucatu) 2018;22(66):801-12. doi: https://doi.org/10.1590/1807-57622017.0473

2. Lima M, Dimenstein M. 0 apoio matricial em saúde mental: uma ferramenta apoiadora da atenção à crise. Interface (Botucatu). 2016;20(58):625-35. doi: https://doi.org/10.1590/1807-57622015.0389

3. Jorge MSB, Diniz AM, Lima LL, Penha JC. Matrix support, individual therapeutic project and prodution in mental health care. Texto Contexto Enferm. 2015;24(1):112-20. doi: https://doi.org/10.1590/0104-07072015002430013

\section{Corresponding author:}

Gustavo Costa de Oliveira

E-mail: gustavoenfufrgs@gmail.com
4. Castro CP, Oliveira MM, Campos GWS. Matrix Support in the SUS of Campinas: how an inter-professional practice has developed and consolidated in the health network. Ciênc Saúde Coletiva. 2016;21(5):1625-36. doi: https://doi. org/10.1590/1413-81232015215.19302015

5. Schutz A. A Construção significativa do mundo social: uma introdução à sociologia compreensiva. Petrópolis: Vozes; 2018.

6. Oliveira GC, Schneider JF, Nasi C, Camatta MW, Olschowsky A. Family expectations about a psychiatric inpatient unit. Texto Contexto Enferm. 2015;24(4):984-92. doi: https://doi.org/10.1590/0104-0707201500000770014

7. Schutz A. El problema de la realidade social. Buenos Aires: Amorrortu; 2015.

8. Rosa AF, Beck GT, Rosas AMMTF, Tito IF, Ferreira T, Santiago AS. Elderly women's perception about nursing gynecological consultation: a comprehensive analysis. Int Arch Med. 2017;10:165. doi: https://doi.org/10.3823/2435

9. Santos RABG, Uchoa-Figueiredo LR, Lima LC. Matrix support and actions on primary care: experience of professionals at ESF and Nasf. Saúde Debate. 2017;41(114):694-706. doi: https://doi.org/10.1590/0103-1104201711402

10. Viana MMO, Campos GWS. Formação Paideia para o Apoio Matricial: uma estratégia pedagógica centrada na reflexão sobre a prática. Cad Saúde Pública. 2018;34(8):e00123617. doi: https://doi.org/10.1590/0102-311×00123617

11. Nogueira FSS, Brito FMG. Diálogos entre saúde mental e atencãa básica: relato de experiência do Pet-Saúde no município de Parnaíba-PI. Pesq Prát Psicossiais. 2017 [cited 2018 Feb 12];12(2):374-87. Available from: http://pepsic.bvsalud.org/scielo. php?script=sci_arttext\&pid=S1809-89082017000200010\&lng=pt\&tlng=pt

12. Schneider JF, Nasi C, Camatta MW, Oliveira GC, Mello RM, Guimarães AN. The Schutzian reference: contributions to the field of nursing and mental health. J Nurs UFPE online. 2017;11(sup|12):5439-47. doi: https://doi. org/10.5205/1981-8963-v11i12a22321p5439-5447-2017

13. Bispo Júnior JP, Moreira DC. Educação permanente e apoio matricial: formação, vivências e práticas dos profissionais dos Núcleos de Apoio à Saúde da Família e das equipes apoiadas. Cad Saúde Pública. 2017;33(9):e00108116. doi: https:// doi.org/10.1590/0102-311×00108116

14. Leite $L S$, Rocha KB. Educação permanente em saúde: como e em que espaços se realiza na perspectiva dos profissionais de saúde de Porto Alegre. Estud Psicol. 2017;22(2):203-13. doi: https://doi.org/10.22491/1678-4669.20170021

15. Iglesias A, Avellar LZ. 0 matriciamento em saúde mental na perspectiva dos gestores. Mental. 2017 [cited 2018 Feb 10];11(20):63-90. Available from: http://pepsic.bvsalud.org/scielo.php?script=sci_arttext\&pid=\$167944272017000100005\&lng=pt\&tlng=pt

16. Barros J0,GonçalvesRMA, KaltnerRP,LancmanS. Matrix supportstrategies:theexperience of two Family Health Support Centers (NASFs) in São Paulo, Brazil. Ciênc Saúde Coletiva. 2015;20(9):2847-56. doi: https://doi.org/10.1590/1413-81232015209.12232014

17. SchranLS,MachineskiGG,RizzottoMLF,CaldeiraS.Themultidisciplinaryteam'sperception on the structure of mental health services: phenomenological study. Rev Gaúcha Enferm. 2019;40(1):e20180151. doi: https://doi.org/10.1590/1983-1447.2019.20180151

18. Campos DB, Bezerra IC, Jorge MSB. Mental health care technologies: primary care practices and processes. Rev Bras Enferm. 2018;71(Supp15):2101-8. doi: https://doi.org/10.1590/0034-7167-2017-0478

19. Nordi ABA, Aciole GG. Apoio matricial: uma experiência da residência multiprofissional em saúde. Trab Educ Saúde. 2017;15(2):485-500. doi: https:// doi.org/10.1590/1981-7746-sol00053

Received: 03.25.2019

Approved: 09.09.2019 